\title{
Public Value of Public Transportation Mode for Urban Communities in Indonesia
}

\author{
Retno Sunu Astuti ${ }^{1}$, Zainal Hidayat ${ }^{2}$, Kushandayani ${ }^{3}$, Aden Nurul Nuha ${ }^{4}$ \\ \{retnosunu@gmail.com ${ }^{1}$ \} \\ Universitas Diponegoro, Indonesia ${ }^{1,2,3,4}$
}

\begin{abstract}
In many developed countries, public transportation modes are the principal options for mobility. On the contrary, the majority people in Indonesia still use personal settlement so that it creates congestion. This indicates that the public has not yet fully utilized public transportation modes for activities. Public value is a public standard assessment of policy, security, and compliance with good policy standards, including public transport service policies. Applying library studies and amplified with qualitative approach, it was discovered that the aversion of urban societies such as Jakarta, Semarang and Malang using public transportation was related to the disparity between the condition of transportation and public transportation provided by the government. Public transportation is a solution to the problem of congestion. As a result, the establishment of public transportations should consider the involved stakeholders' values such as the operators, the public users, government and public. Public transport should be able to have a direct impact of road safety, the efficiency of public mobility, cost affordability, comfort and easy access for disabled people.
\end{abstract}

Keywords: Public Value, Transport Mode, Congestion, Disabilities, Stakeholders

\section{Introduction}

Transportation is an important part of people's social life, because it is a means of connecting input and output in supporting the mobility of community activities. Transportation has an important correlation with population. Indonesia as the 4th country with the largest population in the world needs to regulate the existing transportation system. A good transportation system follows the existing population growth, if the arrangement is wrong it will cause problems, one of which is congestion.

Congestion is caused by the inability of the roads to accommodate the number of existing vehicles. The increase in the number of vehicles is due to the fact that people prefer private vehicles to public transportation. This is because on the one hand people want speed and punctuality in mobility, but on the other hand, people think that the government has not guaranteed the convenience of public transportation. The level of use of public transportation in Indonesia is still low when compared to cities in other countries, the share of public transportation in Jakarta is only $20 \%$ in 2019.

Private vehicles offer flexibility for city dwellers and offer ease of movement for urban communities, but the consequences presented by private vehicles lead to air pollution, noise pollution, increased congestion and health problems for the community. Public transportation in big cities does not yet have a role in replacing private vehicles, causing congestion. Transportation development in Indonesia is slower than neighboring countries such as Malaysia 
and Singapore. The city of Jakarta as the capital of Indonesia had complicated problems in overcoming existing congestion, according to the Institute for Transportation Studies (INSTRAN) in 2020 the number of motorbike users dominated the streets of the Capital City. As much as 72.8 percent of them were motorbike users. Meanwhile, four-wheeled vehicles accounted for $26.5 \%$ and heavy vehicles such as buses or trucks by $0.7 \%$. The well-known location technology institute, TomTom, released the results of the 2019 TomTom Traffic Index, the level of congestion in Jakarta reached $53 \%$. Congestion in the city of Jakarta was based on an increase in vehicles by the growing urban community. The city of Semarang as a city of trade and services also had the same problems as the city of Jakarta, namely the growth of vehicles. Malang as a tourist city also had the same problem in congestion, namely the growth of vehicles.

Efforts to overcome congestion in big cities had been carried out by providing public transportation. The city of Jakarta provides Trans Jakarta, MRT, LRT and KRL. The city of Semarang provided Trans Semarang public transportation based on Bus Rapid Transit, while Malang City used the City Transportation (Angkot).

The existence of public transportation was expected to reduce the use of private vehicles and change people's habits to use public transportation. However, the practice of public interest in using public transportation was not in line with government efforts. In Jakarta, based on data from the Ministry of Transportation, in 2019 the share of public transportation was only 20\%, while in other cities it was under $20 \%$. In big cities in the world such as Singapore, Hong Kong, and Tokyo, it accounted for more than 50\%. Meanwhile, in Kuala Lumpur and Bangkok the level of use of public transportation reached $20-50 \%$.

In the theory of public value, it is explained that if you want to provide a service that is in accordance with the needs of the community, the program must be in accordance with the standards that have been formed in the structure of the needs of the community itself such as security, comfort, convenience, efficiency, and cheapness of cost. Public Value Theory is in line to answer the reluctance of urban communities to use public transportation, so that it is expected to improve the development of value-based public transportation services and community needs.

Rutgers and Overeem [1] in his book 'Creating Public Value' initiated the concept of creating public value as the main focus of managers of public organizations. Public value is defined as a strategic thought and action by public policy makers and managers, in the face of complexity and austerity in assessing the effectiveness and efficiency of public services. The creation of public value lies in the relationship between individuals and society, the emphasis is more on the individual, shaped by subjectivity towards meeting basic needs and the intensity of services provided by the government [2]. This means that public value can be formed if the services produced by public sector organizations can meet community needs and satisfaction.

The main analysis of public value is the public value scorecard of organizational performance [3]. The use of the Public Value Scorecard helps public managers to more systematically overcome trade-offs between financial and non-standard objectives and be able to identify people's needs and concerns [4].

The Public Value Scorecard assessment is based on 5 main questions, namely:

1. Is the program useful?

This analysis will look at the value of the program's usefulness for the community.

2. Is the program feasible?

This analysis will look at the feasibility value on the social side of society.

3. Is the program politically acceptable?

This analysis will look at whether the program is politically accepted.

4. Will the program provide a positive experience?

This analysis will look at the impact of the program on the impacts it will cause. 
5. Is the program profitable?

This analysis will look at the material benefits of the planned program.

The five questions will be a measure of the existence of a public transportation provision program and measure whether it is only limited to political will or desire to reap large profits on the income side or will have a major influence in forming a new experience for the community.

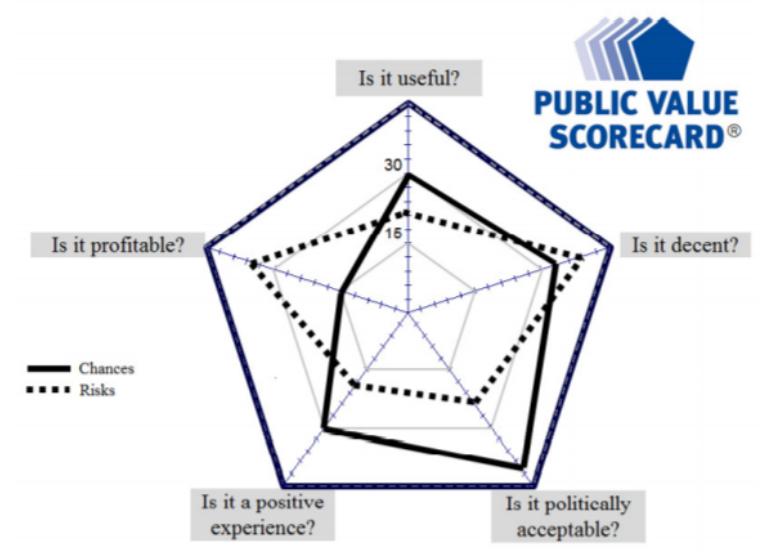

Fig. 1. Scorecard Model by Prof. Peter Gomez and Prof. Timo Meynhardt.

\section{Research Methods}

This research was conducted in three cities, namely Jakarta, Semarang and Malang. The research approach utilized descriptive qualitative methods. This descriptive study aimed at obtaining a detailed description of the state of the object and subject of observation. Data were collected by purposive sampling. Purposive sampling is a data source sampling technique with certain considerations, in this case the users of public transportation.

Data collection techniques in this study were carried out through literature studies and completed through semi-structured interviews with participants to explore public values and find problems more openly in public transportation services so that users of public transportation found it easier to express their opinions. According to Miles and Huberman [5], revealed that the activities in qualitative data analysis were carried out interactively and continued to completion, so that the data was saturated. Therefore, this research was carried out in three stages: (a) data reduction to select the main and important things, so that the data can provide a clear picture; (b) data presentation so that the data is organized and arranged in a relationship pattern so that it is easier to understand; and (c) data verification, namely drawing conclusions and verifying research results. 


\section{Results and Discussion}

Jakarta as a business city had a very high population movement. With the busy activities of its residents, a means of transportation was needed that can meet the need for speed and timeliness, so it was very appropriate that the DKI Jakarta Government provided a mode of transportation with the Bus Rapid Transit (BRT) system or better known as Trans Jakarta. Trans Jakarta's efforts in maximizing services to the community and as a mode of public transportation that can carry large numbers of passengers were carried out by expanding the network. Currently, there were 260 bus stops spread across 13 corridors. In order to provide more satisfying service to passengers, Trans Jakarta also added special routes to reduce passenger density in several corridors and only operate on weekdays. In addition, currently Trans Jakarta had also been integrated with other alternative modes of transportation, namely Jak Linko and MRT (Mass Rapid Transit) as evidence of the seriousness of the DKI Jakarta Government to meet the transportation needs of the Jakarta population.

Trans Jakarta had a high target by 2030, namely the use of transportation modes to reach $62 \%$, currently Trans Jakarta users are at $32 \%$. Apart from the city of Jakarta, Semarang City also used public transportation modes to deal with congestion. Trans Semarang as a mode of public transportation provided options for people in their daily mobility. The presence of Trans Semarang was expected to reduce the number of congestions in the city of Semarang, which had a congestion rate of $37 \%$ per year. Malang City as a tourist city also developed services for existing public transportation by providing public transportation in community mobility.

In fact, people had high hopes for public transportation modes, the main focus of community expectations was a short travel time. In some public transportations in Indonesia, the gap in facilities was still quite high, this was due to the slow pace of upgrading existing facilities, however in several cities facilities on public transportation were starting to become the main focus. In the case of the city of Jakarta, the city government of Jakarta appeared to be investing heavily in improving facilities, starting from replacing old buses with European-style buses or double-decker buses, then changing gasoline to gas or electricity so as not to cause noise in the bus, to the concept of friendly buses. against people with disabilities.

The unfortunate thing did not happen in several public transportation in other cities such as Semarang and Malang, in some cases there were many buses that are not roadworthy, the bus fleet was very limited, the absence of CCTV cameras as security for users, unfriendly stops for people with disabilities to buses who often striked on the road gave a statement that the government was not serious about improving public transportation facilities.

The presence of public transportation in Indonesia had basically been accepted by both the government and the community, in the government environment, the existence of public transportation is the main focus of improvement, this could be seen by the development of several new public transportation modes such as fast trains, MRT, and LRT which will be connected. on an integrated basis. The creation of the Ministry of Transportation and a law related to public transportation, namely Law No. 22/2009 concerning road traffic and transportation, provided a statement that public transportation was politically accepted.

In the community, urban communities in big cities such as Jakarta and Semarang were politically accepted. In the city of Jakarta, public transportation is highly anticipated in overcoming congestion, this could be seen from the increasing enthusiasm of the community, the number of passengers continues to increase every year and it was targeted that the share of public transportation in Jakarta will reach $60 \%$ by 2030.

The presence of public transportation was a long-term investment for the government, the need for consistency in public transportation development was the key to success in a large 
investment in public transportation. Economically, the presence of public transportation suffers losses due to cheap tariffs, but socially the community had a big impact, starting from changing people's behavior or habits, to environmentally friendly sustainability processes. The presence of Trans Jakarta, MRT, and LRT in Jakarta has a big impact on the community because it makes it easy to reach the target areas. On the long-term investment side, the presence of public transportation will increase government revenue in the service sector. Another thing that has an impact is the elimination of congestion in big cities.

\section{Conclusion}

Fundamentally, Public Value will become a new standard in the existence of government programs and become a new benchmark for the government when planning a program so that there is no rejection or uselessness of a program. The presence of public value provides a solution in the development of facilities and infrastructure because there is a win solution as the best way so as not to harm existing stakeholders.

The presence of public transportation in big cities is a way to overcome congestion problems and provide encouragement for changes in people's behavior so as not to live consumptively. However, in reality, the presence of public transportation in big cities such as Jakarta, Semarang and Malang have not provided any benefits. People are still reluctant to use public transportation because of the lack of first impressions. In several cases it was assessed that the government was not ready to provide public transportation.

Public Value on the mode of public transportation shows that the public thinks that the existence of public transportation does not yet have benefits and feasibility for users. Not only that, a positive experience only occurs in Jakarta, in other cities, especially Malang, the existence of public transportation gives a negative impression. Poor facilities such as security, broken bus stops, insufficient number of buses, long waiting times, and not yet friendly public transportation for persons with disabilities make people reluctant to use public transportation.

\section{References}

[1] M. R. Rutgers and P. Overeem, "Public Values in Public Administration Recognizing Public Value.” JSTOR, 2014.

[2] T. Meynhardt, "Public value inside: What is public value creation?," Intl J. Public Adm., vol. 32, no. 3-4, pp. 192-219, 2009.

[3] R. S. Kaplan and D. P. Norton, "The balanced scorecard: measures that drive performance," Harv. Bus. Rev., vol. 83, no. 7, p. 172, 2005.

[4] T. Meynhardt, "Public value: Turning a conceptual framework into a scorecard," 2015.

[5] M. B. Miles, A. M. Huberman, and J. Saldaña, "Qualitative data analysis: A methods sourcebook. 3rd," ed Thousand Oaks, CA Sage, 2014. 